\title{
REMOVAL OF Pb(II) FROM AQUEOUS SOLUTION BY CERAMSITE PREPARED FROM ISFAHAN BENTONITE AND $\gamma$-ALUMINA
}

\author{
Iman Mobasherpour ${ }^{1,}{ }^{凶}$, Masomeh Javaherai ${ }^{1}$, Esmail Salahi ${ }^{1}$, \\ Mohsen Ebrahimi ${ }^{1,2}$, Zahra Ashrafi ${ }^{1}$, Yasin Orooji ${ }^{2}$
}

https://doi.org/10.23939/chcht15.02.263

\begin{abstract}
Removal of lead from aqueous solutions was studied using nanocomposite absorbent of bentonite $/ \gamma$ alumina. The novel absorbent was characterized using XRD, FT-IR and SEM-EDX. Absorption process optimization using response surface methodology (RSM) and experimental design was performed with central composite design technique. The effects of $\mathrm{Pb}$ (II) initial concentration, adsorbent dosage, and composite percentage on $\mathrm{Pb}$ (II) removal percentage and adsorption capacity were examined. The adsorption capacity of $166.559 \mathrm{mg} / \mathrm{g}$ and removal \% of 82.9887 with desirability equal to 0.763 were obtained for optimal initial concentration of $200 \mathrm{mg} \cdot \mathrm{l}^{-1}$, adsorbent dosage of $0.5 \mathrm{mg} \cdot 1^{-1}$, and composite percentage of $7.08 \%$ determined using RSM design. The equilibrium adsorption data were investigated by Langmuir, Freundlich and Dubinin-Radushkevich isotherm models. It was found that Freundlich isotherm model fits better compared with other models.
\end{abstract}

Keywords: removal percentage, $\mathrm{Pb}(\mathrm{II})$, bentonite $/ \gamma$ alumina, response surface methodology.

\section{Introduction}

Today, the presence of heavy metals in environment is a serious threat. Atomic weight of heavy metals is between 63.5 and $200.6 \mathrm{~g} \cdot \mathrm{mol}^{-1}$ and specific gravity is greater than $5 \mathrm{~g} \cdot \mathrm{cm}^{-3}$. Lead is one of heavy metals that enters environment through mining and industrial activities [1].

Lead can cause a lot of damage to human health such as damage to the brain or nervous system, delay in growth and kidney diseases [2]. There are several methods for removing heavy metals from aqueous solutions, for

\footnotetext{
${ }^{1}$ Ceramics Department, Materials and Energy Research Center, P.O. Box 31787-316, Karaj, Iran

${ }^{2}$ College of Materials Science and Engineering, Nanjing Forestry University,

No. 159, LongpanRoad, Nanjing, 210037 Jiangsu, China

${ }^{\otimes}$ Iman.Mobasherpour@gmail.com

(CMobasherpour I., Javaherai M., Salahi E., Ebrahimi M., Ashrafi Z., Orooji Y., 2021
}

example, chemical precipitation, ion exchange, absorption, membrane filtration, coagulation and flocculation, flotation and electrochemical behavior. Among these methods, absorption is of great importance due to being flexible, economic and in some cases reversible [3-6]. Activated carbon is an attractive absorbent, widely used in wastewater treatment worldwide. But it is not economically feasible for small industries due to the need for complex factors to improve absorption performance. Therefore, new low-cost adsorbents such as chitosan, zeolites, clay, peat moss, fly ash, coal, natural oxide, industrial waste, etc. are drawing increasing attention [7]. Low-cost ceramic adsorbent compounds with high specific surface area, called ceramsite, can be useful [8]. Among various absorbents metal oxides nanoparticles such as aluminum oxide, titanium dioxide, zinc oxide, manganese oxide, and cerium oxide are considered for their specific surface area and high activity [9]. Previous research has shown that $\gamma$-alumina is an effective adsorbent to remove lead and even after regenerations may absorb up to $60 \%$ [10]. Also, such lowcost adsorbent as bentonite due to its availability, ion exchange capacity and specific surface area is considered an effective adsorbent. Bentonite from Iran Isfahan shows good results regarding the lead removal from aqueous solutions [11]. Response surface methodology (RSM) was used to solve many problems with industrial equipment. In the last decade, the design of experiments and industrial parameters optimization were considered in the United States and Europe as a key point. In designing experiments, RSM is used to estimate factors and calculations [12].

In Iran, lead diffuses into water and the environment through effluents from lead smelters, as well as from battery, paper, pulp and ammunition industries. To solve the problem, in this work, the synergetic effect of $\gamma$ alumina and bentonite as lead adsorbents was investigated. The effect of various parameters such as the initial concentration of lead, adsorbent dosage and composite percentage on the lead removal and amount of absorption were studied. Since a wide range of variables were examined, it was necessary to carry out many tests. As a result, to save time and cost, central composite design (CCD) of RSM was used. The aim of this study 
was to find an adsorbent with reasonable price and high capacity for the removal of lead and optimize removal rate and absorbed dose using RSM.

\section{Experimental}

\subsection{Materials}

In this research, $\gamma$-alumina powder was purchased from Iranian Nanomaterials Pioneers Co (Iran). Lead nitrate was purchased from Merck (Art No.7397). Bentonite was provided without any modification from Isfahan, Iran. Characterization of nano $\gamma$-alumina and bentonite are given in Table 1.

\subsection{Analysis}

The concentration of $\mathrm{Pb}(\mathrm{II})$ in the solution before and after adsorption were measured by atomic absorption spectrometry (AAS) model GBC 932 plus. Adsorbent XRD patterns were taken using Siemens diffractometer with $\mathrm{Cu} \mathrm{K} \alpha$ radiation $(\lambda=0.1548 \AA)$ at $40 \mathrm{kV}$ and the current of $40 \mathrm{~mA}$. Scanning electron microscopy equipped with energy-dispersive X-ray spectrometer (SEM-EDX) of adsorbent was recorded using VEGA TESCAN. The Fourier transform infrared (FT-IR) spectra of adsorbent (range of $400-4000 \mathrm{~cm}^{-1}$ ) were taken using PerkinElmer model: spectrum 400 .

\subsection{Adsorption Experiments}

The adsorption of $\mathrm{Pb}(\mathrm{II})$ on bentonite $/ \gamma$-alumina (BGA) is done using batch techniques. Adsorption experiments were carried out in a $500 \mathrm{ml}$ glass reactor at the speed of $500 \mathrm{rpm}$, ambient temperature and equilibrium time of $120 \mathrm{~min}$. Bentonite and $\gamma$-alumina were mixed for 10 min with mill. The initial concentrations of $\mathrm{Pb}(\mathrm{II})$, adsorbent dosage and composite percentage arrived from RSM. The adsorption capacity of adsorbent and removal percentage of $\mathrm{Pb}$ (II) from solution were calculated using following equations:

$$
\begin{gathered}
q=\frac{C_{i}-C_{f}}{m} \cdot V \\
\text { \%Removal }=\frac{C_{i}-C_{f}}{C_{i}} \cdot 100
\end{gathered}
$$

where $q$ is the amount of absorbed $\mathrm{Pb}(\mathrm{II}), \mathrm{mg} / \mathrm{g} ; C_{i}$ and $C_{f}$ are the initial and final concentrations of $\mathrm{Pb}(\mathrm{II})$, respectively, $\mathrm{mg} \cdot \mathrm{l}^{-1} ; m$ is the amount of the adsorbent, $\mathrm{g}$; and $V$ is the volume of solution [10].

\subsection{Design of Experiments}

RSM is a statistical method used to optimize experiment parameters [13]. The effects of three independent variables, viz. initial concentration $\left(X_{1}\right)$, adsorbent dosage $\left(X_{2}\right)$, and composite percentage $\left(X_{3}\right)$ on adsorption capacity $\left(Y_{1}\right)$ and \%removal $\left(Y_{2}\right)$ were investigated by central composite design of RSM (Table 2). This behavior is described by quadratic Eq. (3):

$$
Y=\beta_{0}+\Sigma \beta_{i} X_{i}+\Sigma \beta_{i i} X_{i}^{2}+\Sigma \beta_{i j} X_{i} X_{j}
$$

where $Y$ is the response, $\beta_{0}$ is the constant coefficient, $\beta_{i}$ is the linear effect, $\beta_{i i}$ is the square effect, $\beta_{i j}$ is the interaction effect, $X_{i}$ and $X_{j}$ are independent variables.

Also, Design-Expert version 7.1.5 was used in this research. Central composite design (CCD), experiments results and the predicted values along with coded values at 20 runs $\left(6\right.$ central point, 6 axial point and $2^{3}$ factorial points) are shown in Table 3.

Table 1

Characterization of nano $\gamma$-alumina and bentonite

\begin{tabular}{|c|c|c|c|}
\hline \multicolumn{2}{|c|}{$\gamma$-Alumina } & \multicolumn{2}{|c|}{ Bentonite } \\
\hline Average particle size, $\mathrm{nm}$ & 20 & Average particle size, $\mu \mathrm{m}$ & 53.1 \\
\hline Specific surface area, $\mathrm{m}^{2} / \mathrm{g}$ & 138 & Specific surface area, ${ }^{2} / \mathrm{g}$ & 31.0 \\
\hline $\mathrm{Al}_{2} \mathrm{O}_{3}, \%$ & $\geq 99$ & $\mathrm{SiO}_{2}, \%$ & 68.4 \\
\hline $\mathrm{Ca}, \mathrm{ppm}$ & $\leq 25$ & $\mathrm{Al}_{2} \mathrm{O}_{3}, \%$ & 17.7 \\
\hline $\mathrm{Fe}, \mathrm{ppm}$ & $\leq 80$ & $\mathrm{CaO}, \%$ & 2.9 \\
\hline $\mathrm{Cr}, \mathrm{ppm}$ & $\leq 40$ & $\mathrm{Na}_{2} \mathrm{O}, \%$ & 2.8 \\
\hline $\mathrm{Na}, \mathrm{ppm}$ & $\leq 70$ & $\mathrm{MgO}, \%$ & 2.3 \\
\hline $\mathrm{Mn}, \mathrm{ppm}$ & $\leq 3$ & $\mathrm{Fe}_{2} \mathrm{O}_{3}, \%$ & 2.0 \\
\hline $\mathrm{Co}, \mathrm{ppm}$ & $\leq 2$ & $\mathrm{~K}_{2} \mathrm{O}, \%$ & 1.5 \\
\hline & & $\mathrm{SO}_{3}, \%$ & 1.2 \\
\hline
\end{tabular}

Table 2

Coded values and levels of independent variables

\begin{tabular}{|c|c|c|c|c|}
\hline \multirow{2}{*}{ Independent variables } & \multirow{2}{*}{ Code } & \multirow{2}{*}{ Range studied } & \multicolumn{2}{|c|}{ Levels of variables } \\
\cline { 3 - 5 } & & & Low level $(-1)$ & High level $(+1)$ \\
\hline Initial concentration, $\mathrm{mg} \cdot \mathrm{l}^{-1}$ & $X_{1}$ & $200-300$ & 200 & 300 \\
\hline Adsorbent dosage, $\mathrm{g}$ & $X_{2}$ & $0.5-1$ & 0.5 & 1 \\
\hline Percentage composite, $\%$ & $X_{3}$ & $1-10$ & 1 & 10 \\
\hline
\end{tabular}




\section{Results and Discussion}

\subsection{Characteristics of Adsorbent}

The pattern of X-ray diffraction of alumina and bentonite is shown in Fig. 1 before being mixed. Diffraction pattern was investigated, and phases were identified by Xpert software. $\gamma$-Alumina phase (Ref. Code. 00-004-0875) for alumina and phases of montmorillonite (Ref. Code. 00029-1498), quartz (Ref. Code. 01-083-0539), and gypsum
(Ref. Code. 00-006-0047) for bentonite were identified with this software. As can be seen, the main peak of bentonite is observed at $2 \theta=26.4^{\circ}$ and (101) is related to quartz.

\subsection{RSM Results}

RSM is a statistical tool that evaluates the effect of the independent variables on response variables and thus generates a mathematical model [14].Design of the experiment, experimental results, as well as predicted and coded values are presented in Table 3 .

Table 3

Central composite design model, experimental results and predicted values

\begin{tabular}{|c|c|c|c|c|c|c|c|c|c|c|}
\hline \multirow{2}{*}{ Run } & $\begin{array}{c}\text { Initial concentration, } \\
\text { mg. } l^{-1}\end{array}$ & \multicolumn{2}{c|}{$\begin{array}{c}\text { Adsorbent } \\
\text { dosage, }\end{array}$} & \multicolumn{2}{c|}{$\begin{array}{c}\text { Composite } \\
\text { percentage, } \%\end{array}$} & \multicolumn{2}{c|}{ Experimental } & \multicolumn{2}{c|}{ Predicted } \\
\cline { 2 - 12 } & actual & coded & actual & coded & actual & coded & $\begin{array}{c}\text { adsorption } \\
\text { capacity } Y_{1}, \\
\mathrm{mg} / \mathrm{g}\end{array}$ & $\begin{array}{c}\text { removal } \\
\%\end{array}$ & $\begin{array}{c}\text { adsorption } \\
\text { capacity } Y_{1}, \\
\mathrm{mg} / \mathrm{g}\end{array}$ & $\begin{array}{c}\text { removal } \\
\%\end{array}$ \\
\hline 1 & 200 & -1 & 0.5 & -1 & 1 & -1 & 131 & 65.5 & 135.79 & 66.33 \\
\hline 2 & 300 & 1 & 0.5 & -1 & 1 & -1 & 163 & 54.33 & 170.93 & 55.67 \\
\hline 3 & 200 & -1 & 1 & 1 & 1 & -1 & 87.5 & 87.5 & 82.37 & 89.33 \\
\hline 4 & 300 & 1 & 1 & 1 & 1 & -1 & 112.5 & 75 & 117.51 & 78.67 \\
\hline 5 & 200 & -1 & 0.5 & -1 & 10 & 1 & 163 & 81.5 & 150.91 & 78.61 \\
\hline 6 & 300 & 1 & 0.5 & -1 & 10 & 1 & 143 & 47.67 & 155.81 & 52.47 \\
\hline 7 & 200 & -1 & 1 & 1 & 10 & 1 & 95.5 & 95.5 & 97.49 & 101.61 \\
\hline 8 & 300 & 1 & 1 & 1 & 10 & 1 & 112 & 74.67 & 102.39 & 75.47 \\
\hline 9 & 250 & 0 & 0.75 & 0 & 5.5 & 0 & 147.3 & 88.4 & 147.63 & 88.5 \\
\hline 10 & 250 & 0 & 0.75 & 0 & 5.5 & 0 & 147.3 & 88.4 & 147.63 & 88.5 \\
\hline 11 & 250 & 0 & 0.75 & 0 & 5.5 & 0 & 147.3 & 88.4 & 147.63 & 88.5 \\
\hline 12 & 250 & 0 & 0.75 & 0 & 5.5 & 0 & 147.3 & 88.4 & 147.63 & 88.5 \\
\hline 13 & 165.91 & -1.68179 & 0.75 & 0 & 5.5 & 0 & 110.6 & 100 & 115.4652 & 103.9725 \\
\hline 14 & 334.09 & 1.68179 & 0.75 & 0 & 5.5 & 0 & 160.06 & 71.86 & 149.1347 & 73.02751 \\
\hline 15 & 250 & 0 & 0.33 & -1.68179 & 5.5 & 0 & 207.57 & 54.8 & 192.5507 & 56.31832 \\
\hline 16 & 250 & 0 & 1.17 & 1.68179 & 5.5 & 0 & 105.13 & 98.4 & 102.7093 & 94.99956 \\
\hline 17 & 250 & 0 & 0.75 & 0 & 5.5 & 0 & 147.3 & 88.4 & 147.63 & 88.5 \\
\hline 18 & 250 & 0 & 0.75 & 0 & 13.07 & 1.68179 & 112.67 & 67.6 & 103.6197 & 66.32442 \\
\hline 19 & 250 & 0 & 0.75 & 0 & 5.5 & 0 & 147.3 & 88.4 & 147.63 & 88.5 \\
\hline 20 & 250 & 0 & 0.75 & 0 & 5.5 & 0 & 147.3 & 88.4 & 147.63 & 88.5 \\
\hline
\end{tabular}

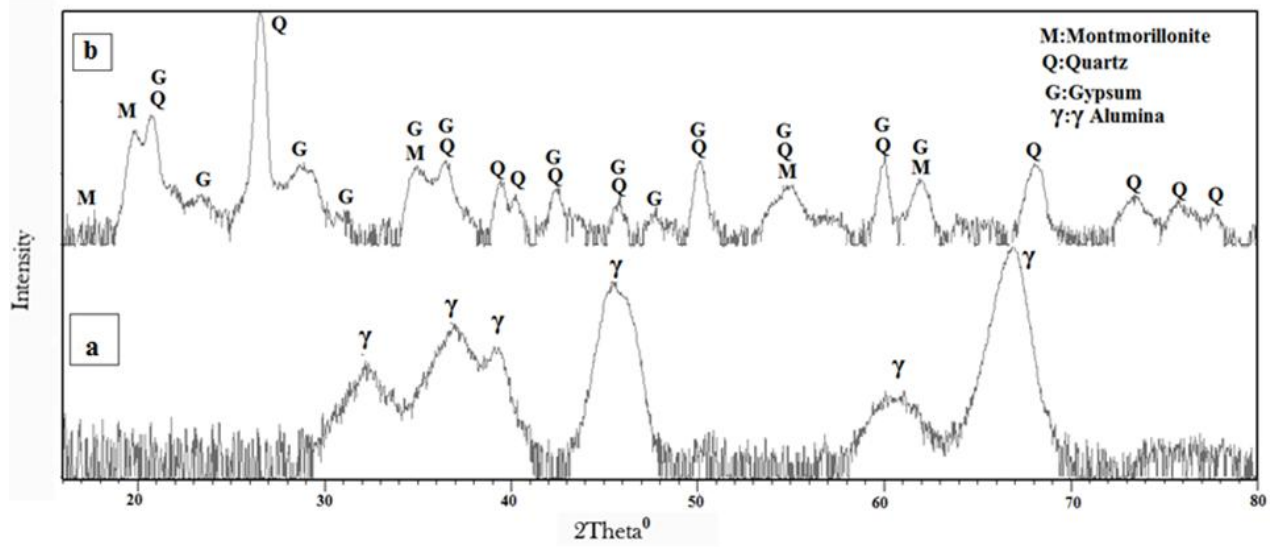

Fig.1. XRD pattern for $\gamma$-alumina (a) and bentonite (b) 
ANOVA table for regression model of adsorption capacity optimization

\begin{tabular}{|l|c|c|c|c|c|}
\hline \multicolumn{1}{|c|}{ Source } & Sum of square & $d f$ & Mean square & $F$ value & $\begin{array}{c}P \text { value } \\
\text { prob }>F\end{array}$ \\
\hline Model & 14347.53 & 9 & 1594.17 & 22.88 & $<0.0001$ \\
\hline A - initial concentration & 1367.94 & 1 & 1367.94 & 19.63 & 0.0016 \\
\hline B - adsorbent dosage & 9743.57 & 1 & 9743.57 & 139.83 & $<0.0001$ \\
\hline C- composite percentage & 70.74 & 1 & 70.74 & 1.02 & 0.3400 \\
\hline AB & 108.78 & 1 & 108.78 & 1.56 & 0.2430 \\
\hline AC & 457.53 & 1 & 457.53 & 6.57 & 0.0306 \\
\hline BC & 2.53 & 1 & 2.53 & 0.036 & 0.8531 \\
\hline $\mathrm{A}^{2}$ & 417.29 & 1 & 417.29 & 5.99 & 0.0369 \\
\hline $\mathrm{B}^{2}$ & 57.19 & 1 & 57.19 & 0.82 & 0.3886 \\
\hline $\mathrm{C}^{2}$ & 1892.60 & 1 & 1892.60 & 27.16 & 0.0006 \\
\hline Residual & 627.14 & 9 & 69.68 & - & - \\
\hline Lack of Fit & 627.14 & 4 & 156.78 & - & - \\
\hline Pure Error & 0.000 & 5 & 0.000 & - & - \\
\hline Cor Total & 15379.43 & 19 & - & - & - \\
\hline
\end{tabular}

Notes: $R^{2}=0.9581, R_{a d j}^{2}=0.9162$, Adeq Precision $=19.987$

\subsubsection{Analysis of variance for absorption capacity}

Interaction between the independent variables and intended response in the equation are given below:

$Y_{1}=147.63+10.01 X_{1}-26.71 X_{2}+2.91 X_{3}+3.69 X_{1} X_{2}$

$-7.56 X_{1} X_{3}-0.56 X_{2} X_{3}-5.42 X_{1}^{2}+2.01 X_{2}^{2}-15.56 X_{3}^{2}$

The variance analysis was performed to know the importance of each response in the regression equation of the model. The results are presented in Table 4. Upper $F$ and lower $P$ values indicate the importance of the regression model and coefficients. Coefficients which have $P<0.05$ are significant. Therefore, according to Table 4 , the coefficients that have $P>0.05$ were removed from the regression equation. The modified equation is presented below:

$$
\begin{gathered}
Y_{1}=147.63+10.01 X_{1}-26.71 X_{2}- \\
-7.56 X_{1} X_{3}-5.42 X_{1}^{2}-15.56 X_{3}^{2}
\end{gathered}
$$

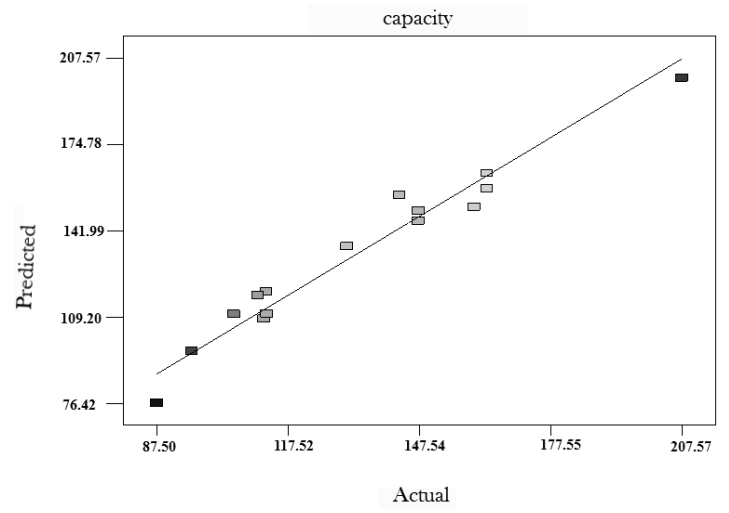

Fig. 2. Graph of predicted and experimental values for adsorption capacity
One can see that the model with $F=22.88$ and $P=0.0001$ has higher significance. In addition to adequate precision, the value larger than 4 is acceptable [15]. An adequate precision of 19.987 shows an adequate signal of adsorption. Competency of the model is investigated by $R^{2}$ and $R_{a d j}$. The $R^{2}$ value of 0.96 indicates closeness of predicted and experimental values. $R_{a d j}{ }^{2}=0.92$ indicates that $92 \%$ from this response is due to independent variables and other $8 \%$ is no longer covered by the model [16]. Fig. 2 shows the predicted by the model graph and experimental values. It shows good distribution of points near the straight line, which indicates good agreement between predicted and experimental values.

\subsubsection{Analysis of variance for $\mathrm{Pb}$ (II) removal percentage}

The relationship between three coded independent variables and their corresponding response are expressed using the following regression equation:

$$
\begin{array}{r}
Y_{2}=88.50-9.20 X_{1}+11.50 X_{2}+2.27 X_{3}+1.46 X_{1} X_{2}-3.87 X_{1} X_{3}- \\
-0.21 X_{2} X_{3}-1.24 X_{1}^{2}-4.54 X_{2}^{2}-9.19 X_{3}^{2}
\end{array}
$$

As previously mentioned, higher $F$ and smaller $P$ values indicated the significance of the regression model and coefficients. The model with higher $F=73.65$ and lower $P=0.0001$ is significant. Coefficients which have $P<0.05$ are significant. According to Table 5, $\mathrm{A}^{2}, \mathrm{AB}$, $\mathrm{BC}$ coefficients are removed from the equation due to $P>0.05$, and the modified equation is as follows:

$$
\begin{gathered}
Y_{2}=88.50-9.20 X_{1}+11.50 X_{2}+ \\
+2.27 X_{3}-3.87 X_{1} X_{3}-4.54 X_{2}^{2}-9.19 X_{3}^{2}
\end{gathered}
$$


Table 5

ANOVA table for regression model of removal percentage optimization

\begin{tabular}{|l|c|c|c|c|c|}
\hline \multicolumn{1}{|c|}{ Source } & Sum of square & $d f$ & Mean square & $F$ value & $\begin{array}{c}P \text { value } \\
\text { prob }>F\end{array}$ \\
\hline Model & 4206.18 & 9 & 467.35 & 73.65 & $<0.0001$ \\
\hline A- initial concentration & 1156.15 & 1 & 1156.15 & 182.20 & $<0.0001$ \\
\hline B-adsorbent dosage & 1804.79 & 1 & 1804.79 & 284.43 & $<0.0001$ \\
\hline C-composite percentage & 43.07 & 1 & 43.07 & 6.79 & 0.0285 \\
\hline $\mathrm{AB}$ & 17.02 & 1 & 17.02 & 2.68 & 0.1359 \\
\hline $\mathrm{AC}$ & 120.05 & 1 & 120.05 & 18.92 & 0.0019 \\
\hline $\mathrm{BC}$ & 0.35 & 1 & 0.35 & 0.055 & 0.8199 \\
\hline $\mathrm{A}^{2}$ & 21.72 & 1 & 21.72 & 3.42 & 0.0973 \\
\hline $\mathrm{B}^{2}$ & 291.86 & 1 & 291.86 & 46.00 & $<0.0001$ \\
\hline $\mathrm{C}^{2}$ & 659.88 & 1 & 659.88 & 103.99 & $<0.0001$ \\
\hline Residual & 57.11 & 9 & 6.35 & - & - \\
\hline Lack of Fit & 57.11 & 4 & 14.28 & - & - \\
\hline Pure Error & 0.000 & 5 & 0.000 & - & - \\
\hline Cor Total & 4351.77 & 19 & - & - & - \\
\hline
\end{tabular}

Notes: $R^{2}=0.9866, R_{A d j}^{2}=0.9732$, Adeq Precision $=27.653$

Adequate precision indicates the signal to noise ratio. An adequate precision value greater than 4 is desirable and at this response it is 27.653 , which shows adequate signal of adsorption. $R^{2}$ and $R_{a d j}{ }^{2}$ are 0.99 and 0.97 , respectively, which shows that this regression model has higher competency in comparison with the regression model of the "adsorption capacity" response. Fig. 3 shows the predicted graphs using the model and experimental values for the percentage removal of $\mathrm{Pb}(\mathrm{II})$. This represents that the points in Fig. 3 have a more appropriate distribution and are closer to the straight line.

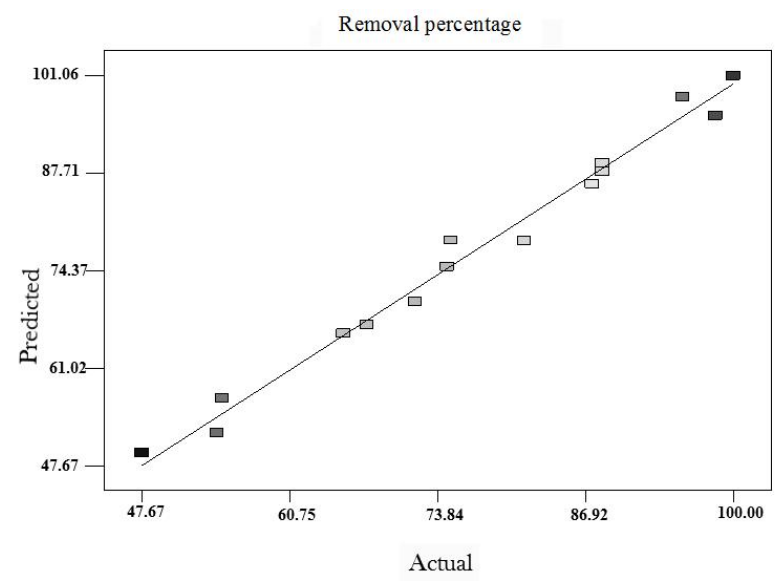

Fig.3. Graph of predicted and experimental values for removal percentage

\subsubsection{Three-dimensional (3d) and contour plots for absorption capacity}

Three-dimensional (3d) plots and contour plots are corresponding with those provided in Figs. 4 and 5. The effect of the composite percentage and adsorbent dosage on the absorption capacity is shown in Figs. 4a and 5a, and the $\mathrm{Pb}$ (II) initial concentration is preserved at $250 \mathrm{mg} / \mathrm{l}$. By increasing adsorbent dosage from 0.5 to $1 \mathrm{~g}$, absorption capacity is reduced so it can be mentioned that when adsorbent dosage is low, the entire absorbent surface is exposed to the absorbent and is fullysatiate. For this reason, it increases absorption capacity, but higher absorption value at the adsorbent surface generates heterogeneous sites, thus, the adsorbent surface does not reach the saturation point and reduces the absorption capacity [17]. By increasing the composition percent, the absorption capacity initially is increased and then decreased; so it has no significant effect. In Figs. $4 \mathrm{~b}$ and $5 \mathrm{~b}$ similar changes are observed in the percentage of the composite, and increase in the concentration from 200 to $300 \mathrm{mg} / \mathrm{l}$ strongly increases the absorption capacity, because more $\mathrm{Pb}$ (II) ions are perched at subject absorbent [18]. Figs. 4c and 5c indicate changes in absorption capacity relative to the initial concentration of lead and the adsorbent dosage. When $\mathrm{Pb}(\mathrm{II})$ concentration is low and adsorbent dosage is high, the absorption capacity is low; increasing $\mathrm{Pb}$ (II) concentration and reducing adsorbent dosage increases the absorption capacity, this means the maximum capability of the absorbent for absorption.

\subsubsection{Three-dimensional (3d) and contour plots for $\mathrm{Pb}(\mathrm{II})$ removal percentage}

In Figs. 6 and 7 three-dimensional (3d) plots and contour plots are presented to evaluate the effect of independent variables on the removal percentage of $\mathrm{Pb}(\mathrm{II})$. Figs. 6a and $7 \mathrm{a}$ show the effect of adsorbent 
dosage and composite percentage on removal percentage of $\mathrm{Pb}(\mathrm{II})$. As can be seen, with the increase in the adsorbent dosage, the removal percentage increases and as was predicted, composite percentage has no significant effect on the removal percentage. With increasing the adsorbent dosage, active sites are increased [19], which leads to the increase in the $\mathrm{Pb}$ (II) removal percentage. Figs. $6 \mathrm{~b}$ and $7 \mathrm{~b}$ show graphs of composite percentage and concentration. They show that the composite percentage does not have high sensitivity to $\mathrm{Pb}(\mathrm{II})$ concentration and with the increase in this value, the removal percentage is initially increased and then decreased. With the increase in
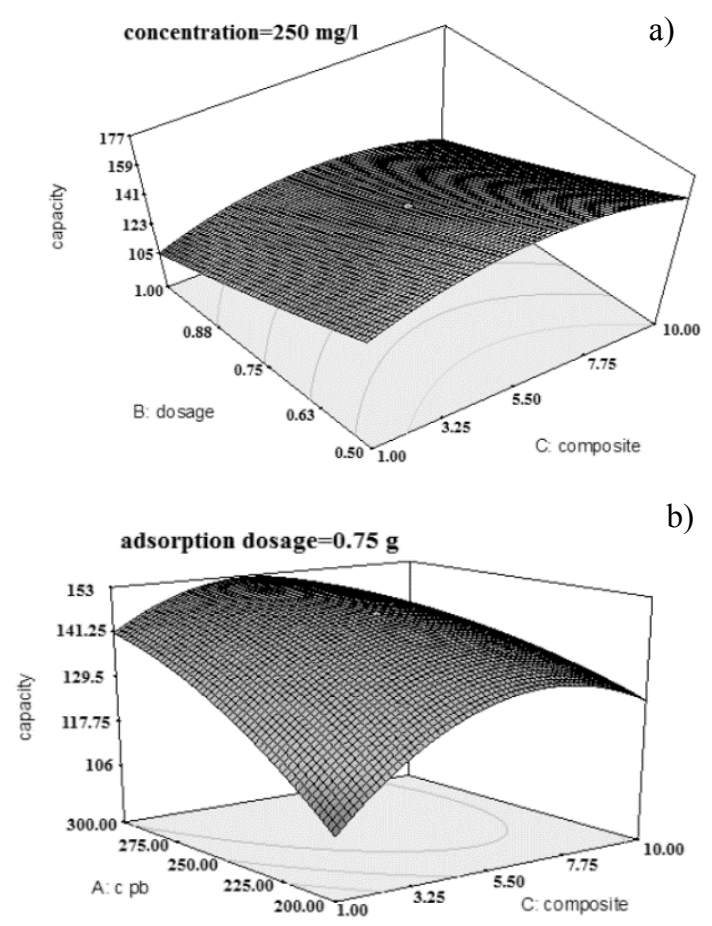

b)

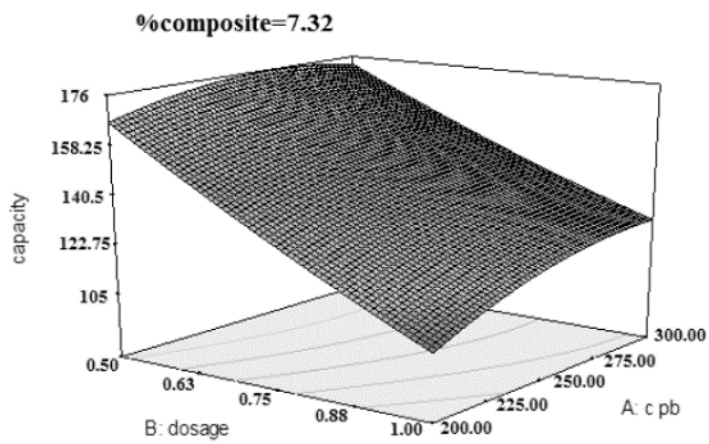

Fig.4. Three-dimensional (3d) plots for the effect of composite percentage and adsorbent dosage (a); composite percentage and initial concentration (b); initial concentration and adsorbent dosage (c) on adsorption capacity
$\mathrm{Pb}$ (II) concentration, removal percentage decreases and, in fact, the increase in the composite percentage does not affect it. Figs. 6c and 7c show the effect of adsorbent dosage and $\mathrm{Pb}(\mathrm{II})$ concentration, while composite percentage is kept constant at 5.5. At low concentrations the removal percentage is high, and decreases with increasing concentration, because the impregnation of absorbent sites by $\mathrm{Pb}$ (II) in a certain concentration decreases the removal percentage. At higher concentrations of $\mathrm{Pb}(\mathrm{II})$, and increasing the absorbent dosage, the removal percentage increases due to the increase of active sites [20].
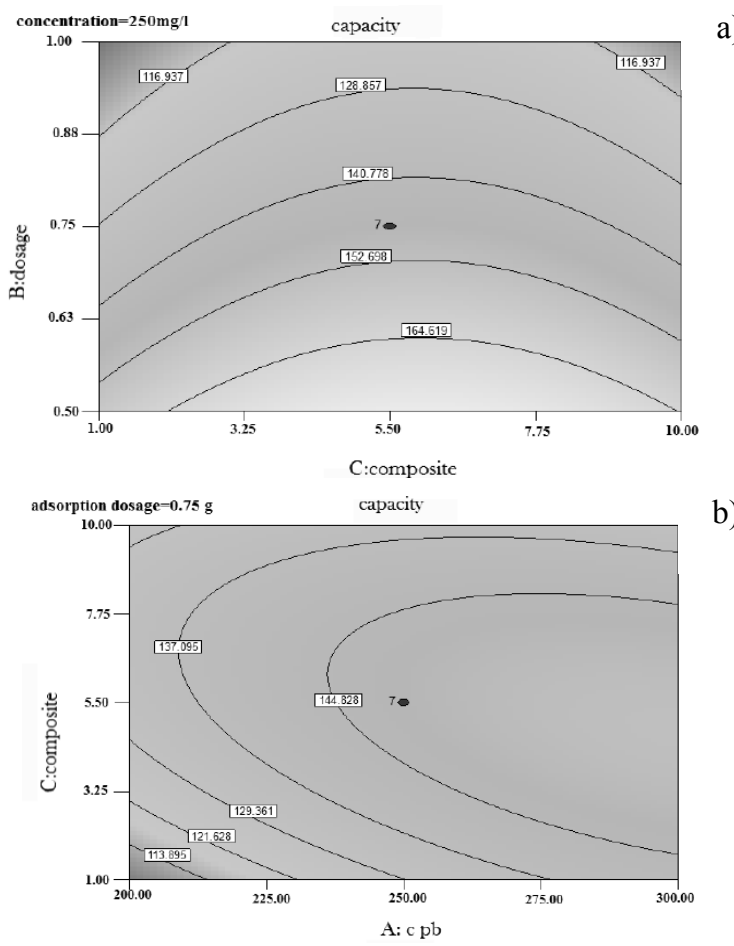

b)

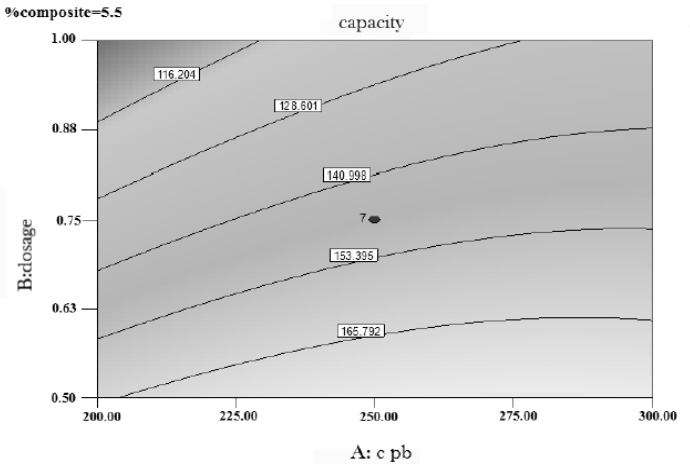

c)

Fig.5. Contour plots for the effect of composite percentage and adsorbent dosage (a); composite percentage and initial concentration (b); initial concentration and adsorbent dosage (c) on adsorption capacity 


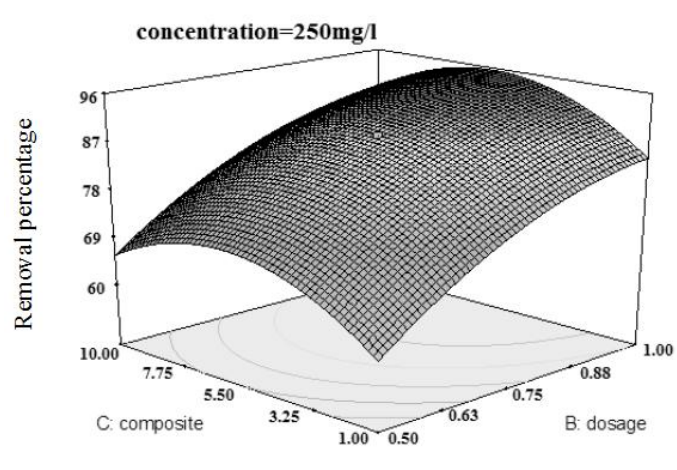

a)

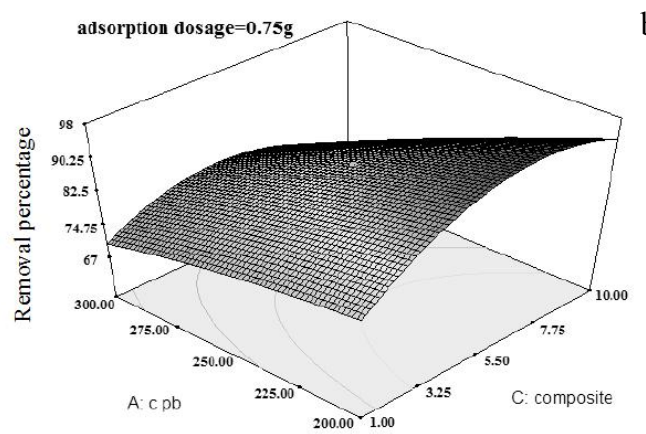

b)

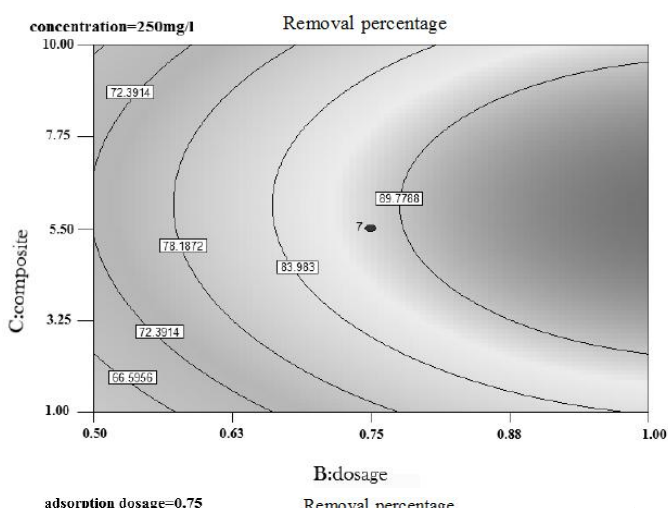

a)

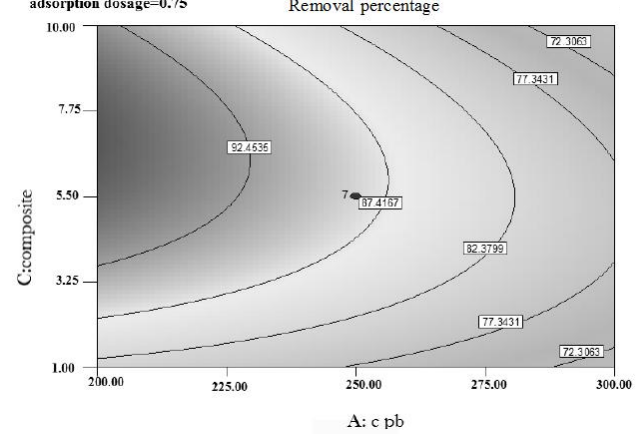

b)

c)

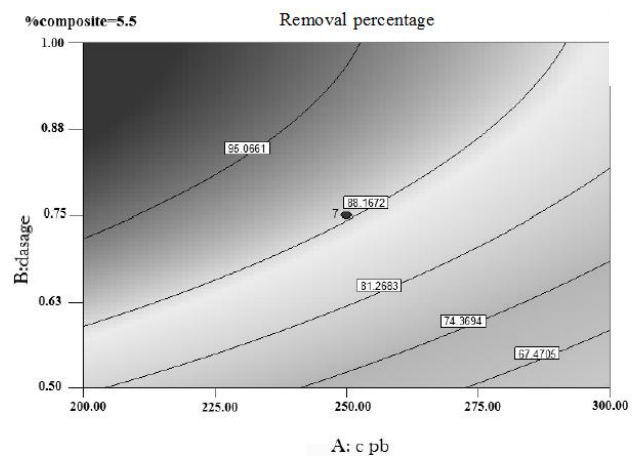

c)

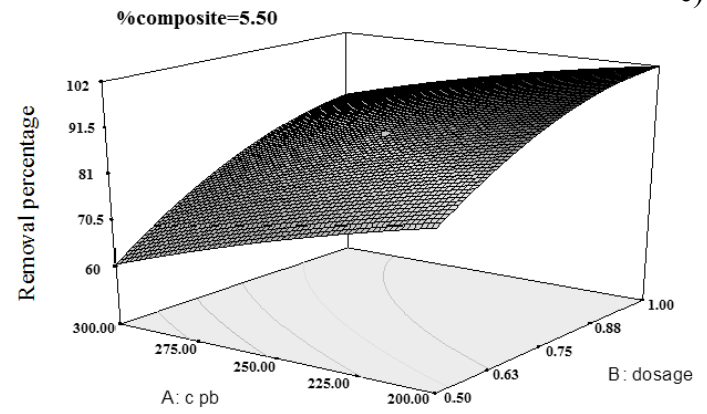

Fig.6. Three-dimensional (3d) plots for the effect of composite percentage and adsorbent dosage (a); composite percentage and initial concentration (b); initial concentration and adsorbent dosage (c) on removal percentage

\subsubsection{Optimization}

Numerical optimization methods have been used to obtain optimal results as well as responses to maximum values, the amount of adsorbent dosage in minimum amount, $\mathrm{Pb}(\mathrm{II})$ initial concentration and composite percentage in the permitted range. The optimal values were initial concentration $\left(200 \mathrm{mg} \cdot \mathrm{l}^{-1}\right)$, adsorbent dosage $\left(0.5 \mathrm{mg} \cdot \mathrm{l}^{-1}\right)$, composite percentage $(7.08 \%)$, adsorption capacity $(166.559 \mathrm{mg} / \mathrm{g})$ and removal percentage (82.9887 \%) with desirability equal to 0.763 . According to these conditions, experiment was performed with the results matching the adsorption capacity of 163 and \%removal of 81.5 , which indicates the predicted values were close to the actual values.

Fig.7. Contour plots for the effect of composite percentage and adsorbent dosage (a); composite percentage and initial concentration (b); initial concentration and adsorbent dosage (c) on removal percentage

\subsection{Adsorption Investigations}

\subsubsection{XRD results}

The XRD patterns of BGA with the highest removal percentage and maximum absorption are presented in Fig. 8 according to which the adsorption of $\mathrm{Pb}$ (II) by BGA only slightly affects peak displacement. There are the main peaks for (a) and (b) at $2 \theta=26.7^{\circ}$ and $26.5^{\circ}$, respectively.

\subsubsection{FT-IR analysis}

The FT-IR spectra of BGA before adsorption (a), BGA with maximum absorption (b) and BGA with maximum removal percentage (c) are seen in Fig. 9. The 
stretching vibration produced from $\mathrm{Al}-\mathrm{OH}$ and $\mathrm{Si}-\mathrm{OH}$ stretching was observed at 3625,3630 and $3631 \mathrm{~cm}^{-1}$. The broad bands at 3434,3448 and $3455 \mathrm{~cm}^{-1}$ are related to the $\mathrm{H}-\mathrm{OH}$ stretching vibration [21]. The bands at 1640, 1641 and $1642 \mathrm{~cm}^{-1}$ are related to water $\mathrm{OH}$ bending vibration. The broad band is appeared at $1389-1400 \mathrm{~cm}^{-1}$ (Figs. 9b and 9c) depending on stretch mode $\mathrm{NO}_{3}{ }^{-}$[22]. This is the reason for absorption of lead nitrate by adsorbent. In addition, the displacement of wave numbers in (b) and (c) to (a) indicates the absorption of lead. As a result, lead absorption does not affect the BGA crystalline structure and only slightly affects peaks and hydrogen bonds [11]. Available band at $1039 \mathrm{~cm}^{-1}$ indicates $\mathrm{Si}-\mathrm{O}-\mathrm{Si}$ stretching vibration, the band at $523 \mathrm{~cm}^{-1}$ corresponds to $\mathrm{Si}-\mathrm{O}-\mathrm{Si}$ bending vibration and at $467 \mathrm{~cm}^{-1}-$ to $\mathrm{Si}-\mathrm{O}-\mathrm{Al}$ bending vibration.

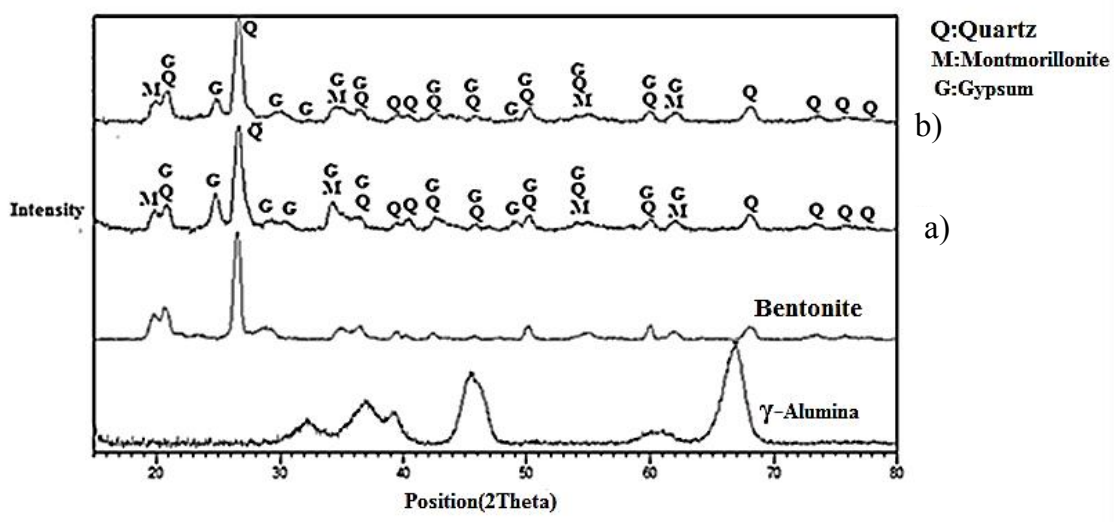

Fig.8. XRD pattern for BGA with maximum absorption (a) and the highest removal percentage (b)

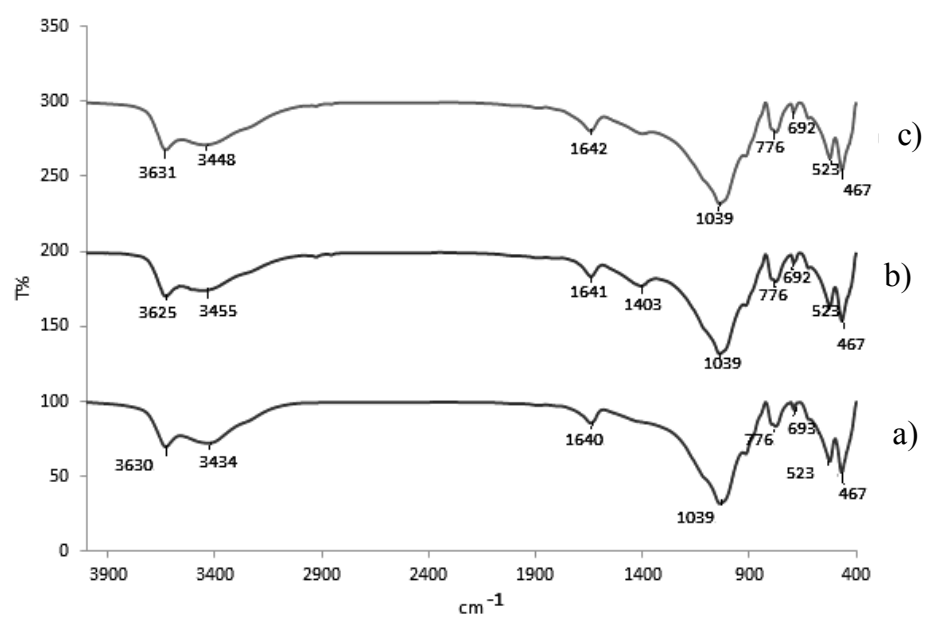

Fig.9. FT-IR spectra for BGA before absorption (a); with maximum absorption capacity (b) and maximum removal percentage (c)

\subsubsection{SEM-EDX analysis}

SEM-EDX images are shown in Fig. 10. Fig. 10a shows that raw bentonite before $\mathrm{Pb}(\mathrm{II})$ adsorption and being mixed with $\gamma$-alumina is in the form of laminate. The values of weight percent of elements (Fig. 10b) show that aluminum amount is $7.65 \mathrm{wt} \%$. Figs. $10 \mathrm{c}$ and $10 \mathrm{~d}$ shows that after mixing bentonite with alumina and absorption lead, the aluminium percent is $10.94 \mathrm{wt} \%$, which indicates the addition of $\gamma$-alumina to raw bentonite. Lead amount of $16.21 \mathrm{wt} \%$ is indicative of maximum adsorption capacity. Also, lead amount of $10.46 \mathrm{wt} \%$ is indicative of maximum removal percentage. Weight percent of lead in the sample with maximum adsorption capacity is higher than that in the sample with maximum removal percentage.

\subsection{Adsorption Isotherms}

The isotherm graphs display how the adsorbate is distributed between the liquid and solid phases in equilib- 
rium [23]. There are several models for adsorption isotherm. Langmuir, Freundlich and Dubinin-Radushkevich isotherm models are used in this research.

Langmuir equation is as follows [24, 25]:

$$
\frac{C_{e}}{q_{e}}=\frac{1}{k_{L} q_{m}}+\frac{C_{e}}{q_{m}}
$$

where $q_{e}$ is adsorption capacity at the equilibrium, $\mathrm{mg} / \mathrm{l}$; $q_{m}$ is the maximum adsorption capacity for adsorbent, $\mathrm{mg} / \mathrm{g} ; C_{e}$ is the equilibrium concentration, $\mathrm{mg} / \mathrm{l} ; k_{L}$ is the Langmuir constant related to adsorption energy, $1 / \mathrm{mg}$.

Freundlich equation is as follows [24,25]:

$$
q_{e}=k_{f} C_{e}^{1 / n}
$$

where $k_{f}$ and $n$ are the Freundlich constants.
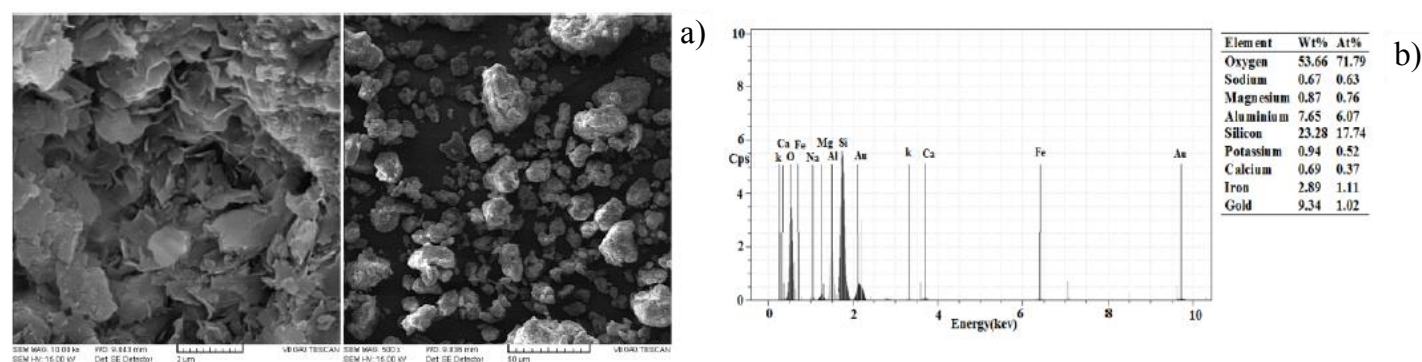

Dubinin-Radushkevich equation is as follows [24, 25]:

$$
\ln q_{e}=\ln X_{m}-\beta \varepsilon^{2}
$$

where $X_{m}$ is the maximum adsorption capacity, $\mathrm{mg} / \mathrm{l} ; \beta$ is the activity coefficient related to the average absorbed energy and $\varepsilon$ is Dubinin-Radushkevich isotherm constant. The parameter $\varepsilon$ can be calculated by Eq. (11):

$$
\varepsilon=R T \ln \left(1+\frac{1}{C_{e}}\right)
$$

where $R$ is the gas constant; $T$ is an experimental temperature, here $298 \mathrm{~K}$.

According to Eq. (10) the equation for sorption energy (Eq. (12)) is obtained:

$$
E=\frac{1}{\sqrt{2 \beta}}
$$
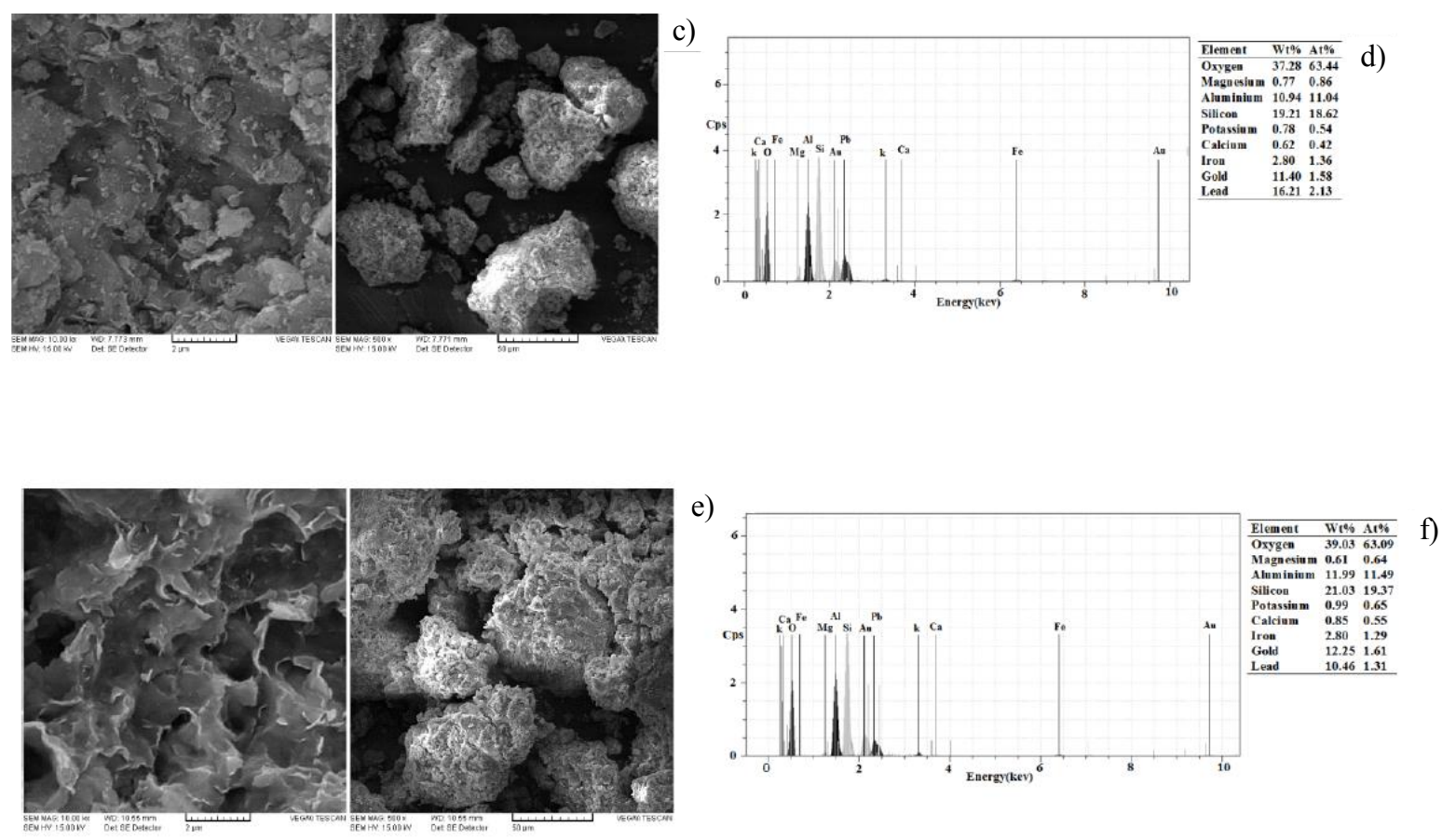

Fig. 10. SEM-EDX pictures for raw bentonite ( $a, b)$; BGA with maximum adsorption capacity $(c, d)$ and BGA with maximum removal percentage $(e, f)$ 
Isotherm coefficients for $\mathrm{Pb}$ (II) removal

\begin{tabular}{|c|c|c|}
\hline \multirow{2}{*}{ Isotherm model } & \multicolumn{2}{|c|}{ Coefficients } \\
\hline \multirow{3}{*}{ Langmuir } & $R^{2}$ & 0.9915 \\
\cline { 2 - 3 } & $q_{e}$ & 126.582 \\
\cline { 2 - 3 } & $k$ & 0.069 \\
\hline \multirow{3}{*}{ Freundlich } & $R^{2}$ & 0.9973 \\
\cline { 2 - 3 } & $n$ & 5.516 \\
\cline { 2 - 3 } & $k_{f}$ & 1.365 \\
\hline \multirow{3}{*}{ Dubinin-Radushkevich } & $R^{2}$ & 0.9713 \\
\cline { 2 - 3 } & $X_{m}$ & 1388.14 \\
\cline { 2 - 3 } & $\beta$ & $2 \cdot 10^{-9}$ \\
\hline
\end{tabular}
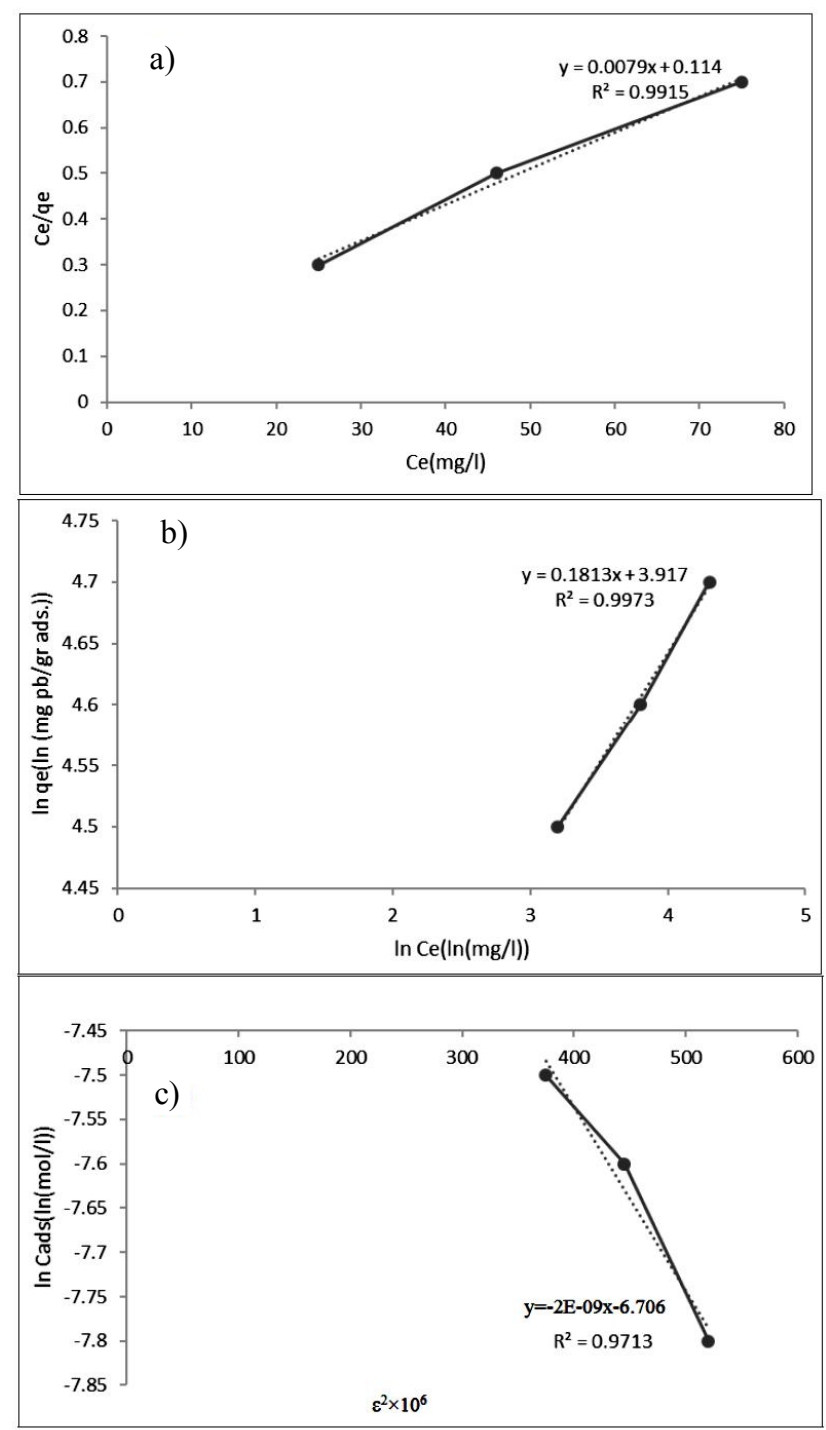

Fig. 11. Isotherm graphs for Langmuir model (a); Freundlich model (b)and DKR model (c)
Coefficients obtained from each equation and graphs depending on the adsorption model are provided in Table 6 and Fig. 11. The Pb(II) concentrations were 200, 250 and $300 \mathrm{mg} / \mathrm{l}$. Based on the correlation coefficients (for Langmuir model $R^{2}=0.9915$, for Freundlich model $R^{2}=0.9973$ and for Dubinin-Radushkevich model $R^{2}=0.9713$ ), the Freundlich model is the best available model among adsorption isotherm models. By measuring the sorption energy an appropriate indicator is obtained to determine the absorption type. If the absorption energy is less than $8 \mathrm{~kJ} \cdot \mathrm{mol}^{-1}$ then the type of adsorption is physical; if absorption energy is between $8-16 \mathrm{~kJ} \cdot \mathrm{mol}^{-1}$, then the type of adsorption is ion exchange mechanism and if absorption energy is more than $16 \mathrm{~kJ} \cdot \mathrm{mol}^{-1}$, then the type of adsorption is strong chemical mechanism of cation exchange [26]. The value of absorption energy $E=15.811 \mathrm{~kJ} \cdot \mathrm{mol}^{-1}$, so the adsorption mechanism is determined as ion exchange mechanism.

\section{Conclusions}

In this study, a novel absorbent mixture of bentonite and nano $\gamma$-alumina was obtained. The effectiveness of the adsorbent for removal of $\mathrm{Pb}$ (II) from aqueous solutions has been investigated. The results of SEM-EDX, FT-IR spectroscopy and XRD analysis well confirmed lead absorption. RSM was used for variables optimization. The adsorption capacity of $166.559 \mathrm{mg} / \mathrm{g}$ and removal \% of 82.9887 with desirability equal to 0.763 were obtained for optimal initial concentration of $200 \mathrm{mg} \cdot 1^{-1}$, adsorbent dosage of $0.5 \mathrm{mg} \cdot 1^{-1}$, and composite percentage of $7.08 \%$ determined using RSM design. The RSM results show that the composite percentage has no significant effect on the adsorption capacity and removal percentage, and these two responses are affected by the initial concentration of $\mathrm{Pb}(\mathrm{II})$ and adsorbent dosage. 
Langmuir, Freundlich and Dubinin-Radushkevich isotherm models were used. Freundlich isotherm model was the best model with $R^{2}=0.9973$. According to the value of absorption energy $E=15.811 \mathrm{~kJ} \cdot \mathrm{mol}^{-1}$, the adsorption mechanism is of ion exchange type.

\section{References}

[1] Gumpu M., Sethuraman S., Krishnan U., Rayappan J.: Sensor Actuat.B-Chem, 2015, 213, 515.

https://doi.org/10.1016/j.snb.2015.02.122

[2] Barakat M.: Arab. J. Chem., 2011, 4, 361.

https://doi.org/10.1016/j.arabjc.2010.07.019

[3] Fu F., Wang Q.: J. Environ.Manage., 2011, 92, 407.

https://doi.org/10.1016/j.jenvman.2010.11.011

[4] Aminul Islam Md., Morton D., Johnson B.et al.: J.Water

Process. Eng., 2018, 26, 264.

https://doi.org/10.1016/j.jwpe.2018.10.018

[5] Lu F., Astruc D.: Coord. Chem. Rev.,2018, 365, 147.

https://doi.org/10.1016/j.ccr.2017.11.003

[6] Singh N., Nagpal G., Agrawal S., Rachna: Environ. Technol.

Innovat., 2018, 11, 187. https://doi.org/10.1016/j.eti.2018.05.006

[7] Babel S.: J. Hazard. Mater., 2003, 97, 219.

https://doi.org/10.1016/s0304-3894(02)00263-7

[8] Yuan L., Liu Y.: Chem. Eng. J., 2013, 215, 432.

https://doi.org/10.1016/j.cej.2012.11.016

[9] Hua M., Zhang S., Pan B.et al.: J. Hazard. Mater., 2012, 211,

317. https://doi.org/10.1016/j.jhazmat.2011.10.016

[10] Bhat A., Megeri G., Thomas C.et al.: J. Environ.Chem. Eng.,

2015, 3, 30. https://doi.org/10.1016/j.jece.2014.11.014

[11] Sadeghalvad B., Karimi H., Hosseinzadegan H., Azadmehr A.:

Desalin.Water Treat., 2014, 52, 6440.

https://doi.org/10.1080/19443994.2013.823352

[12] Myers R., Montgomery D., Anderson-Cook C.: Response

Surface Methodology: Process and Product Optimization using

Designed Experiments, $4^{\text {nd }}$ edn. John Wiley \& Sons 2016.

[13] Murugesan A., Vidhyadevi T., Kalaivani S.et al.: J. Water

Process. Eng., 2014, 3, 132.

https://doi.org/10.1016/j.jwpe.2014.06.004

[14] Zhen H., Xu-Tao Z., Gui-Qing X.: Proceed. Int. Conf. on Technology Innovation and Industrial Management, 2013, 120.

[15] Ahmad R., Hasan I.: Environ.Nanotechn., Monitor. Manage., 2016, 6, 116. https://doi.org/10.1016/j.enmm.2016.09.002

[16] Kaynar Ü., Şabikoğlu I., Kaynar S.,Eral M.: Appl. Radiat. Isot., 2016, 115, 280. https://doi.org/10.1016/j.apradiso.2016.06.033
[17] Savasari M., Emadi M., Bahmanyar M., Biparva P.: J. Ind.

Eng. Chem., 2015, 21, 1403.

https://doi.org/10.1016/j.jiec.2014.06.014

[18] Hamane D., Arous O., Kaouah F.et al.: J. Environ.Chem. Eng., 2015, 3, 60. https://doi.org/10.1016/j.jece.2014.11.003

[19] Kalantari K., Ahmad M., Masoumi H.et al.: Int. J. Mol. Sci., 2014, 15, 12913. https://doi.org/10.3390/ijms 150712913

[20] Zamani S., Salahi E., Mobasherpour I.: Res.Chem.Intermed., 2014, 40, 1753. https://doi.org/10.1007/s11164-013-1078-3

[21] Toor M., Jin B., Dai S., Vimonses V.: Ind. Eng. Chem. Res., 2015, 21, 653. https://doi.org/10.1016/j.jiec.2014.03.033

[22] Ranđelović M., Purenović M., Zarubica A.et al.: J. Hazard. Mater., 2012, 199, 367.

https://doi.org/10.1016/j.jhazmat.2011.11.025

[23] Can N., Ömür B., Altındal A.: Sensor. Actuat. B-Chem., 2016, 237, 953. https://doi.org/10.1016/j.snb.2016.07.026

[24] Mobasherpour I., Salahi E., Ebrahimi M.: Res. Chem. Intermed., 2012, 38, 2205. https://doi.org/10.1007/s11164-012-0537-6

[25] Mobasherpour I., Salahi E., Pazouki M.: Desalination, 2011, 266, 142. https://doi.org/10.1016/j.desal.2010.08.016

[26] Doğan M., Alkan M., Demirbaş Ö.et al.: Chem. Eng. J., 2006, 124, 89. https://doi.org/10.1016/j.cej.2006.08.016

Received: February 14, 2019/Revised: March 18, 2019 / Accepted: August 30, 2019

\section{ВИДАЛЕННЯ Рb(II) 3 ВОДНОГО РОЗЧИНУ КЕРАМЗІТУ, ПРИГОТОВАНОГО ІЗ СУМІШІ ІСФАХАНСЬКОГО БЕНТОНІТУ ТА $\gamma$-ОКСИДУ АЛЮМІНІЮ}

Анотація.Досліджено процес видалення свинцю з водних розчинів за допомогою нанокомпозитного абсорбенту бентоніт/ $\gamma$-оксид алюмінію. Характеристику нового абсорбентупроведено з використанням рентгенівської дифрактометрії, Фур 'є спектороскопіїта скануючої електронної мікроскопії. Оптимізацію процесу проведено з використанням методології поверхні відгуку (RSM) та центрального композичійногоплану експерименту. Досліджено вплив початкової концентрації $\mathrm{Pb}(I I)$, дози адсорбенту та композиційного відсотку на ступінь видалення Pb(II) та адсорбиійну здатність. За ізотермічними моделями Лангмюра, Фрейндліха та Дубініна-Радушкевича досліджено прочес адсорбиії. Встановлено, щзо ізотермічна модель Фрейндліха підходить краще у порівнянні з іншими моделями.

Ключові слова: ступінь видалення, $\mathrm{Pb}(\mathrm{II})$, бентоніт $/ \gamma$ оксид алюмінію, методологія поверхні відгуку. 